\title{
Interaction between Stock Prices and Exchange Rate in Emerging Market Economies
}

\author{
Serpil Kahraman Akdogu ${ }^{1}$ \& Ayse Ozden Birkan ${ }^{1}$ \\ ${ }^{1}$ Department of Economics, Faculty of Economics and Administrative Sciences, Yasar University, Izmir, Turkey. \\ Correspondence: Serpil Kahraman Akdogu, Department of Economics, Faculty of Economics and Administrative \\ Sciences, Yasar University, Izmir, Selcuk Yasar Campus, Universite cad. No:35-37, Turkey. Tel: 90-232-411-5216.
}

Received: March 29, 2016

Accepted: April 9, 2016

Online Published: April 15, 2016

doi:10.5430/rwe.v7n1p80

\author{
URL: http://dx.doi.org/10.5430/rwe.v7n1p80
}

\begin{abstract}
In this study we apply a series of non-causality tests to determine the direction of the relationship between stock price indices and exchange rates in emerging market economies. The data set includes monthly observations for the 21 countries included in the MSCI Emerging Markets Index between January 2003 and June 2013. The results indicate that there is a statistically significant causal interaction between the two variables in 13 of the 21 countries we study. The direction of the causality varies from country to country and is subject to the joint effect of multiple factors depending on the particulars of the economy in question.
\end{abstract}

Keywords: exchange rate, stock price, Granger causality, Toda-Yamomoto test, bootstrap causality test

\section{Introduction}

Exchange rates and stock prices play a major role both in fostering financial sector development and in aggrevating financial crises. Financial crises have become a worldwide phenomenon after 1980s when most emerging market economies opened their doors to foreign investors. Due to an increased openness of the financial markets, contagion effect appears to be a financial risk that all agents are facing during their economic activities (Duric, 2006). In the last decade, the world economy has witnessed two major financial crises: 2008 global financial crisis, and the eurozone sovereign debt crisis. During each crisis period, it is observed that stock prices and foreign exchange rates act as barometers of the financial system. They are very sensitive to shifting market conditions. High volatility in the financial system has negative implications for all economic agents. The main hazard brought about by high volatility is the unpredictability of the cost of capital which undermines the efficient allocation of funds. It should be noted that financial markets fail to allocate the funds with full efficiency even in the best of scenarios due to many factors like less than rational behavior by investors, complex innovative financial products, high transaction and information costs, psychological factors, etc. High volatility exacerbates the situation. A financial instability in which financial system is no longer able to efficiently channel funds to most productive investment opportunities may lead to a sharp decline in economic activity. On top of this, the rise in intereste rates, incerase in stock prices and the increase in uncertainty worsen the asymmetric information problem in financial markets (Mishkin, 2001). If the sequence of financial market phenomena which create the instability can be traced and causal relationships can be established, policy makers could prevent financial instability and make sure that financial markets contribute to sustainable growth.

There are two theoretical approaches to the issue of the nature and the direction of the relationship between exchange rates and stock prices: stock oriented models and flow oriented models. This study offers an empirical analysis of the 21 countries included in the MSCI-EM index in order to understand if the traditional approach or the portfolio approach is empirically valid in emerging market economies. Most of the empirical research on the interaction between stock prices and the exchange rate has been on developed economies while research on emerging market economies is confined to small groups of Asian countries. To the best of our knowledge, this study is the first to look at such a wide selection of emerging market economies simultaneously.

The paper is organized as follows. After the introduction section, the second section provides a literature review. In the third section, data and modelling are explained while the emprical results and the methodology are given in the following section. Finally, the last section concludes the paper. 


\section{Theoretical Framework}

In the finance literature there is no theoretical or empirical consensus regarding the nature and the direction of the relationship between exchange rates and stock prices. There are two theoretical approaches to the issue: stock oriented models and flow oriented models.

Flow oriented model or the traditional approach, initially developed as a model of exchange rate determination, suggests that the stock market reacts to changes in exchange rates which are the result of the current account performance of the country. Since stock prices represent the present value of the future cash flow of the firms, they are affected by changes in international competitiveness and the trade balance brought about by changes in the exchange rate. If there is a depreciation, for example, international competitiveness of domestic firms will improve and the profits of the firm and consequently the stock price of the firm will increase, hence a positive relation between exchange rates and stock prices.

On the other hand, stock oriented models or the portfolio balance approach suggests the causality runs from stock market to exchange rates. These models focus on the financial (capital) account as the main determinant of exchange rate dynamics. The mechanism can be conceptialized either in terms of the demand and supply of money or in terms of decisions on an internationally diversified portfolio. For instance, a value loss in stock prices may lead to a decrease in the wealth of investors and lower their demand for money with the consequence of lowering the interest rate; this in turn would lead to capital outflows and a depreciation of the domestic currency. Equivalently, the fall in stock prices would lead to decreasing demand for domestic assets and increasing demand for foreign assets and consequently for the foreign currency needed to carry out these purchases. This brings about a depreciation of the domestic currency (Dornbusch, 2001). As a result, stock prices and exchanges are negatively related.

There is no reason to expect only one of these theories to be empirically valid; all of the mechanisms mentioned above may be simultaneously at work. Thus the nature of the relation between stock prices and the exchange rate is likely to be dependent on the particulars of individual countries as well as the global conjuncture.

\section{Literature Review}

A large body of literature focuses on developed countries rather than emerging market economies or cross-country studies. Studies by Dilrukshan, Richards, Simpson and Evans (2009), Beer and Habein (2008), Staverek (2005), Yang and Doong (2004), Morley (2002), and Nieh and Lee (2001) present some examples of the work on developed countries. The empirical literature on emerging market economies on the other hand is confined to Asian economies.

Abdalla and Murinde (1997) examine the relationship for four emerging market economies; India, Pakistan, S. Korea, Philipines. The authors apply an error correction model by using montly data from Internatinal Finance Corporation (IFC) stocks and real exchange rates for the period from January 1985 to July 1994. The results indicate that causality runs from exchange rates to stock prices in India, Pakistan and S. Korea while in Philipines, it runs in the opposite direction.

Ayaji, Friedman and Mehdian (1998) perform the Granger causality test to determine the direction of the causality between the stock market and the currency market. They observe that causality runs from the currency market to the stock market in Korea while the reverse is observed for Phillipines and Indonesia. Furtermore, the data of Hong Kong, Singapore, Malaysia and Thailand indicate no significant relation. The authors also explain the differences in their findings for seven advanced economies from 1985 to 1991 and eight Asian emerging market economies from 1987 to 1991.

1997 Asian crisis sparked growing interest in Asian countries. Granger, Huangb and Yang (1998) is one such study which focuses on nine Asian countries including Hong Kong, Indonesia, South Korea, Taiwan, Thailand, Philippines, Malaysia, Singapore and Japan. The authors use daily data from January 1986 to November 1997, during the Asian crisis. The data of Japan and Thailand support the traditional approach, so that exchange rates lead stock prices with a positive correlation. In the case of Taiwan, the analysis shows that causality runs from stock prices to exchange rates with a negative correlation as an example of portfolio balance approach. The results indicate strong feedback relations for Indonesia, Korea, Malaysia and the Philippines while no causality exist for Singapore. A subsequent version of this paper, Granger, Huangb and Yang (2000) covers the period from January 3, 1986 to June 16, 1998. They observe that causality runs from exchange rates to stock prices for Korea while in Philippines, it runs in the opposite direction. Further, the data of Hong Kong, Malaysia, Singapore, Thailand and Taiwan indicate strong feedback relation while Indonesia and Japan indicate no relation between the exchange rate and the stock market indices. 
Moreover, Muhammed and Rasheed (2002) explore the interaction between stock prices and exchange rates for four South Asian countries; Bangladesh, Sri Lanka, India and Pakistan. They perform a cointegration test, error correction modelling and a Granger causality test for the time span between January 1994 and December 2000. However, they find no association between the variables for Pakistan and India while bidirectional long-run causality in the Bangladesh and Sri Lanka data is observed. They conclude that the variables are unrelated in the short-run for the countries that they selected.

In the Malaysian context, Ibrahim and Aziz (2003) employ cointegration analysis and vector autoregression modelling. Authors use monthly data from January 1977 to August 1998 when capital controls were in place and a fixed exchange rate was imposed by the government. They also consider the effect of the Asian crisis on the interaction among the variables. They investigate the interactions between Malaysian equity market and four macroeconomic variables; real output, price level, money supply and exchange rate. Their results show that unstable interactions between the stock prices and exchange rates exist during the crisis period. In addition to this, they note that they doubt whether the Asian crisis has changed the relationships among variables.

Another empirical study which considers the 1997 Asian crisis is a study of Hatemi-J and Roca (2005). They select four countries as a sample; Malaysia, Indonesia, Phillipines and Thailand and employ bootstrap causality tests. The authors point out that in the non-crisis period there is a significant interaction between stock prices and exchange rates in all countries with the exception of Phillipines.

Pan, Chi-Wing Fok and Y. Liu (2007) investigate the causal relationship between exchange rates and stock prices for Hong Kong, Japan, Korea, Malaysia, Singapore, Taiwan, and Thailand. They use data over the the period between January 1988 and October 1998. They examined the issue for the two subperiods: before the 1997 Asian financial crisis period and the crisis period. Their results shows that causality runs from exchange rates to stock prices for Hong Kong, Japan, Korea, Singapore, Taiwan and Thailand during the Asian crisis. The results indicate that the causality runs from stock prices to exchange rates for Hong Kong, Korea and Singapore while they also observe causality in the opposite direction in Hong Kong, Japan, Malaysia and Thailand in pre-crisis period. Additionally, they note that the role of the trade volume, the exchange rate regime, the degree of capital control as well as the size of equity market influence the nature of the interaction between variables.

Agrawal, Kumar Srivastav and Srivastava (2010) apply the Granger causality test to examine the dynamics between Nifty returns and the Indian Rupee-USD exchange rates, using daily data for the period between October 2007 to March 2009. Their results support unidirectional causality runing from stock returns to exchange rates with a negative correlation.

Muhammed and Rasheed (2002) apply Granger causality and bivariate cointegration tests to determine the interaction between the two variables for Pakistan, India, Sri Lanka and Bangladesh. They use monthly data from January 1994 to December 2000. The results indicate that stock prices and exchange rates do not exhibit a long-run relation in Pakistan and India while a long-run relation exist for Bangladesh and Sri Lanka. Moreover there is no short run causality for any of the four countries.

Smyth and Nandha (2003) focus on the same South Asian countries as Muhammed and Rasheed (2002) and perform Engle-Granger and Johansen cointegration tests by using daily data from 1995 to 2001. Contrary to those of Muhammed and Rasheed (2002), the empirical findings of this study suggest that there is no long-run interaction between the two variables in any of the selected countries. In addition to this, there is is uni-directional causality running from exchange rates to stock prices in India and Sri Lanka, while no short run interaction exists between the two variables exists in Bangladesh and Pakistan.

There are also studies like those of Mahmood and Dinniah (2007), Muller and Verschoor (2007), and Rahman and Uddin (2009) which investigate the interaction between exchange rates and stock prices using Johansen's cointegration methodology on selected Asian countries.

On the other hand, an analysis of the long run causation between stock prices and exchange rates in the context of a multivariate model can be found in the works of Md-Yusuf and Rahman (2013), Ray (2012), and Dimitrova (2005).

In the Malaysian context, Md-Yusuf and Rahman (2013) examine the Granger causality effect and point out that there is feedback between the two markets.

Dimitrova (2005) focuses on the United Kindom and the United States by using monthly data from January 1990 to August 2004. The author states that an increase in stock prices leads to a decrease in exchange rates while a weak association exist between exchange rates and stock prices; depreciation of the currency may lead to decrease the stock market to decline. 
Moreover, Ray (2012) performs a multiple regression model to test the impact of different macroeconomic variables on the stock prices and the multivariate granger causality test to determine the interaction between macroeconomic variables and stock prices for India using annual data from 1990 to 1991 and from 2010 to 2011. The results of Granger causality test indicate that unidirectional causality exists between stock prices and inflation rate, stock prices and foreign direct investment, stock prices and gross domestic product, stock prices and exchange rates, stock prices and gross fixed capital formation while bi-directional causality exist between stock prices and foreign exchange reserve, stock prices and the money supply, stock prices and crude oil price, stock prices and the overall price index. Furthernore, there is no causal interaction between stock prices and the interest rate, stock prices and the index of industrial production.

Our study aims at contributing to this literature by extending the analysis to a wider range of emerging market economies, namely Latin American and European emerging market economies cited in the MSCI-EM index. Thus any overarching tendency with regards to the interaction of stock prices and exchange rates in emerging markets can be diagnosed.

\section{Data}

Our dataset consists of 126 monthly observations on the stock price indices and the exchange rates (US dollars per domestic currency) of the 21 countries included in the MSCI Emerging Markets Index over the January 2003-June 2013 period. Figure 1 presents the data in natural logarithms.

\section{Brazil}

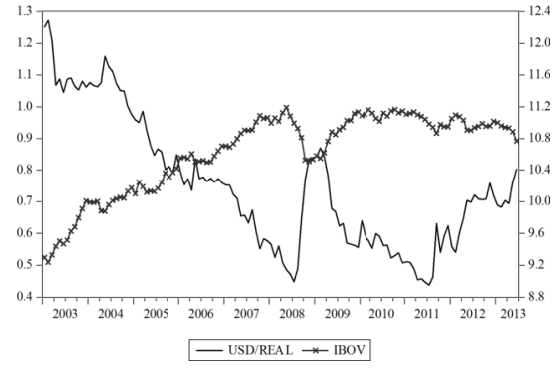

Chile

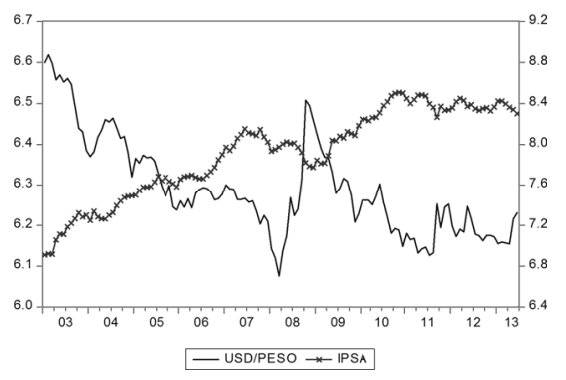

China

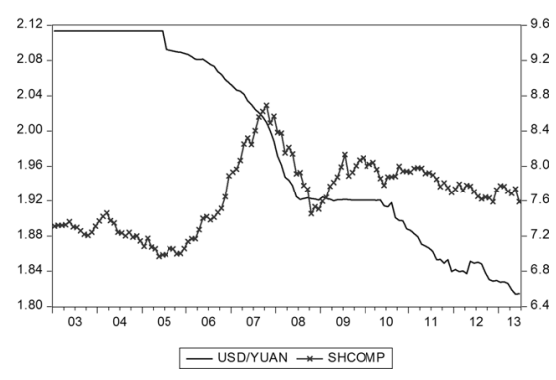

Egypt

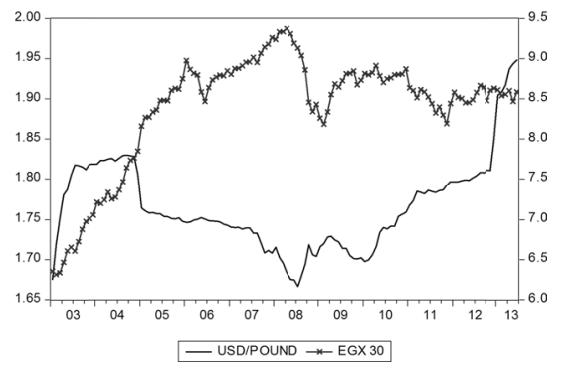

Hungary

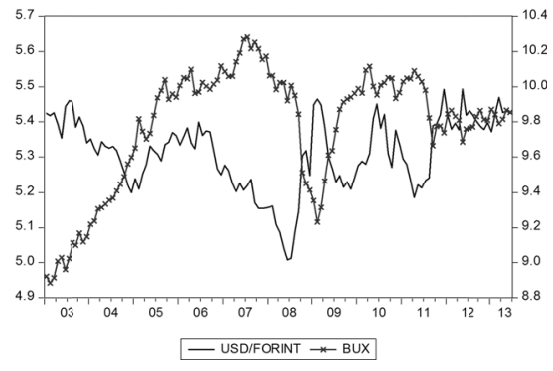

India

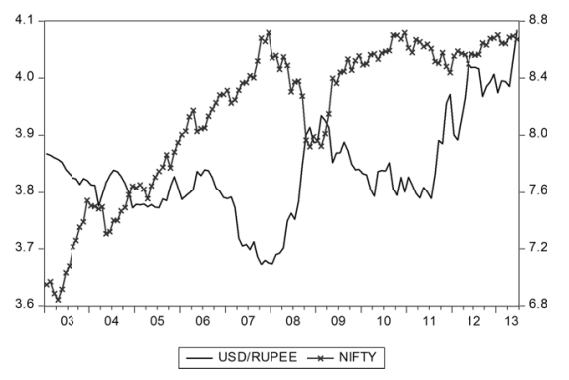




\section{Columbia}

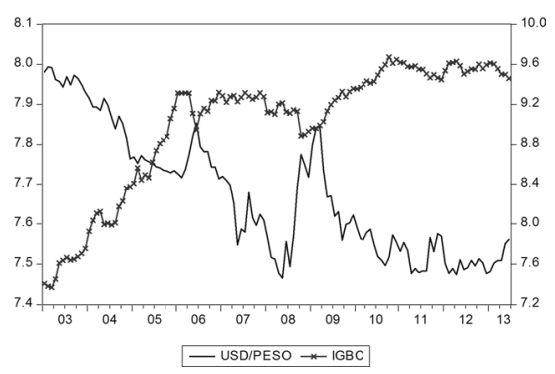

\section{Czech Republic}

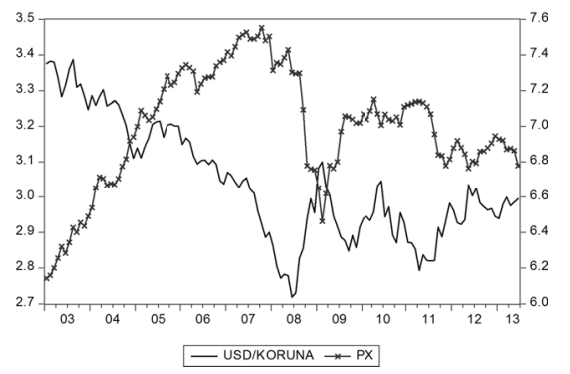

\section{Malaysia}

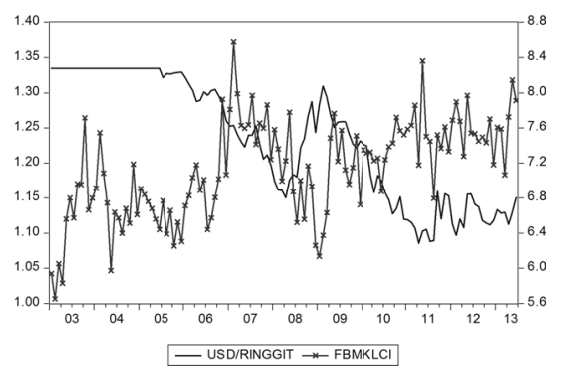

\section{Mexico}

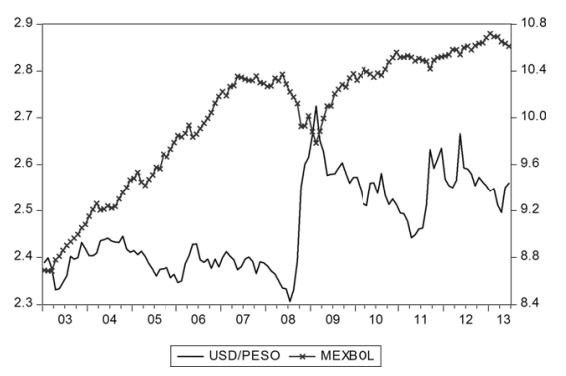

\section{Morocco}

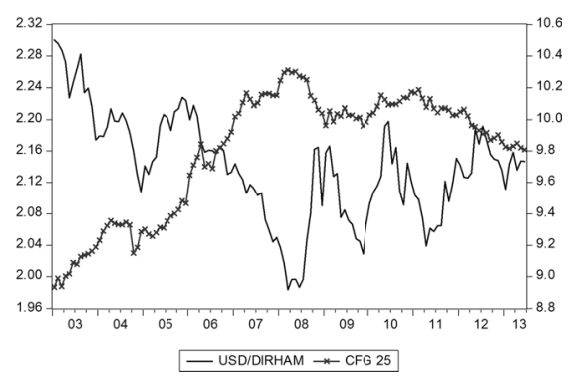

\section{Indonesia}

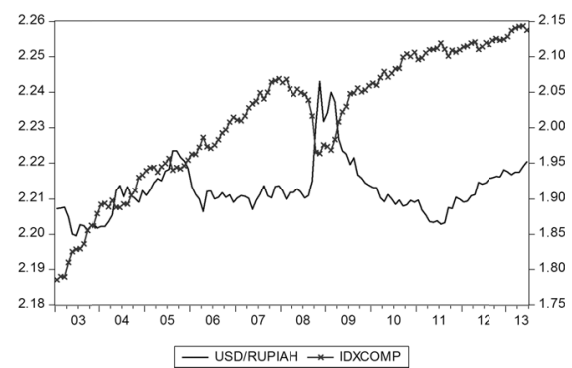

\section{South Korea}

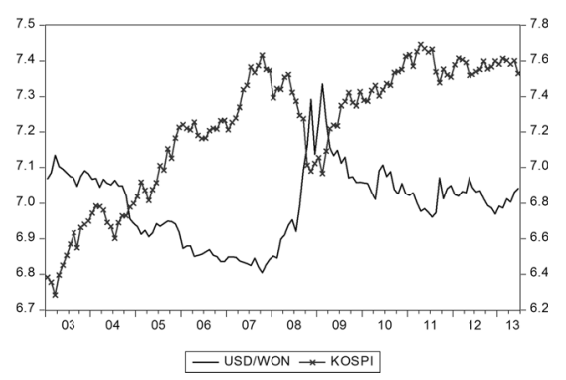

\section{Poland}

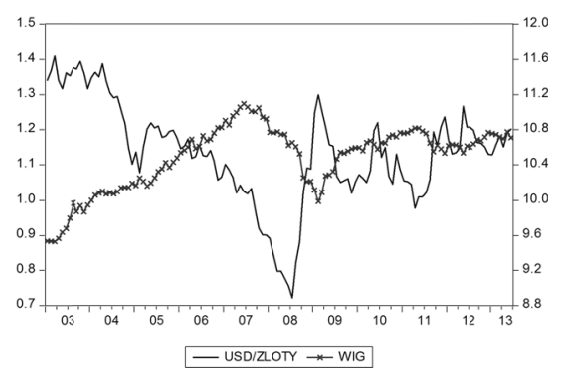

Russia

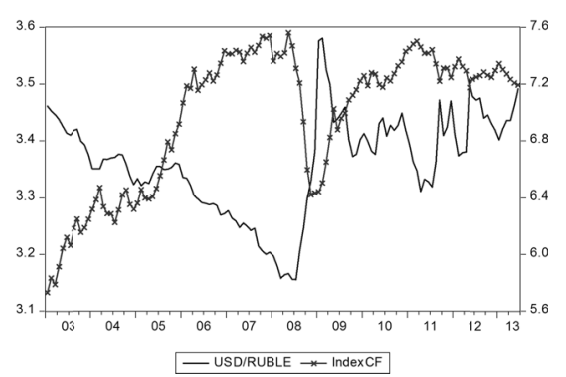

\section{South Africa}

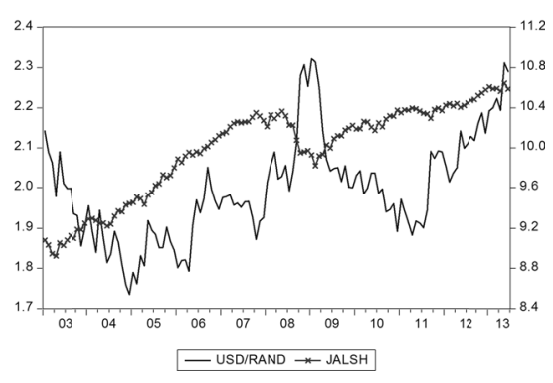




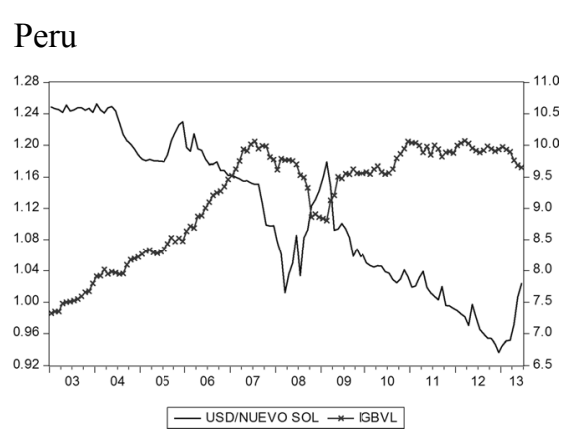

Philippines

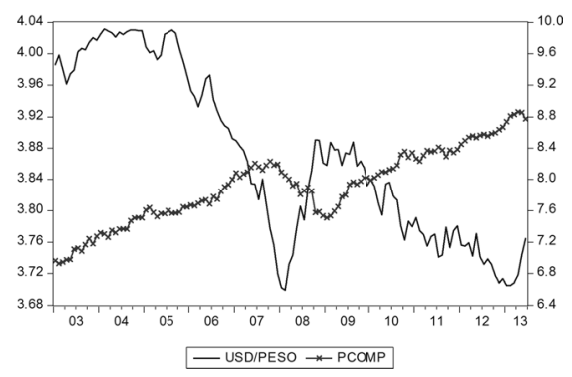

Turkey

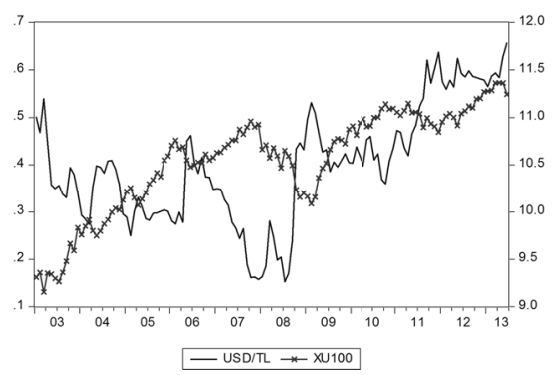

\section{Taiwan}

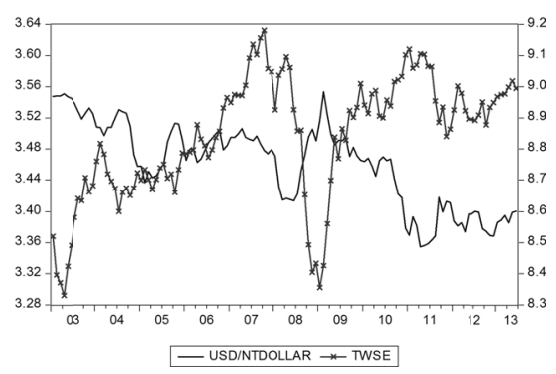

Thailand

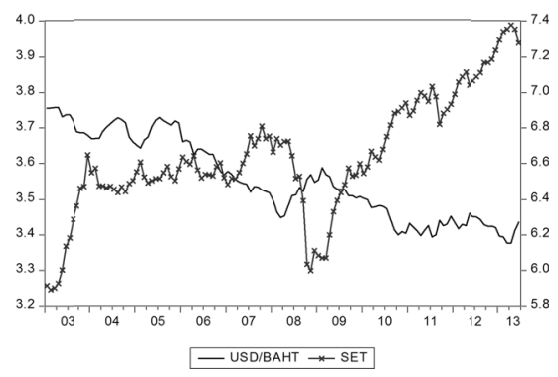

Figure 1. Exchange rates and stock indices in natural logarithms (Jan 2003-Jun 2013)

For the period in question the single most important disturbance is the global financial crisis of 2008.For some countries like Hungary, the Czech Republic, Egypt, India, Morocco Poland and Turkey the crisis meant a trend reversal in the exchange rates bringing about a trend of depreciation for the local currency in the aftermath of the crisis. On the other hand the local currency in countries like Brazil, Chile, China, Colombia, Peru, Philippines, Taiwan and Thailand continued to appreciate after the initial impact of the global crisis. Stock market performance has been sluggish in some of these 21 emerging market economies since 2008 while the upward trend of the stock indices has been intact for Indonesia, Mexico, Philippines, Thailand, South Africa and Turkey after a quick recovery.

Visual inspection of the data does not yield any clues for a generalization regarding which variable leads. It is presumable that each country has its own distinct structural characteristics that affect the nature of the interaction between stock prices and the exchange rate. Table 1 presents some relevant characteristics of the 21 countries. 
Table 1. Countries included in the MSCI-EM index

\begin{tabular}{|c|c|c|c|c|c|c|}
\hline & Brazil & Chile & China & Colombia & Czech & Egypt \\
\hline $\mathbf{a}$ & São Paulo SE & Santiago SE & Shangai SE & $\begin{array}{l}\text { Colombia } \\
\text { SE }\end{array}$ & Prague SE & $\begin{array}{l}\text { Egyptian } \\
\text { Exchange }\end{array}$ \\
\hline b & IBOV & IPSA & SHCOMP & IGBC & PX & EGX 30 \\
\hline c & $353+11$ & $225+20$ & $954+0$ & $76+6$ & $29^{*}$ & $234+1$ \\
\hline d & 54.60 & 116.78 & 44.94 & 70.87 & 18.99 & 22.55 \\
\hline $\mathbf{e}$ & 37.05 & 17.42 & 70.82 & 7.03 & 5.22 & 7.84 \\
\hline f & 0.64 & 0.49 & 0.56 & 0.58 & n.a. & 0.46 \\
\hline $\mathbf{g}$ & -2.12 & -1.31 & 1.86 & -2.83 & -2.83 & -2.32 \\
\hline $\mathbf{h}$ & 2.89 & 9.13 & 3.83 & 4.00 & 1.04 & -0.20 \\
\hline $\mathbf{i}$ & 0.29 & 1.80 & 0.07 & 0.59 & 0.00 & -0.30 \\
\hline $\mathbf{j}$ & 2252.66 & 268.31 & 8227.10 & 369.81 & 195.66 & 257.29 \\
\hline $\mathbf{k}$ & 0.87 & 5.56 & 7.80 & 4.00 & -1.32 & 2.21 \\
\hline 1 & 5.40 & 3.01 & 2.65 & 3.18 & 3.30 & 7.12 \\
\hline m & Brazilian real & Chilean peso & $\begin{array}{l}\text { Yuan } \\
\text { (Renminbi) } \\
\text { strictly }\end{array}$ & $\begin{array}{l}\text { Colombian } \\
\text { peso }\end{array}$ & Koruna & $\begin{array}{l}\text { Egyptian } \\
\text { pound }\end{array}$ \\
\hline n & free float & free float & $\begin{array}{l}\text { managed float } \\
\text { after } 2005\end{array}$ & managed & free float & free float \\
\hline
\end{tabular}

\begin{tabular}{lllllll} 
& Hungary & India & Indonesia & Korea & Malaysia & Mexico \\
\hline a & Budapest SE & National SE & Indonesia & Korea & Bursa & Mexican \\
b & BUX & NIFTY & SE & Exchange & Malaysia & Exchange \\
c & $51+1$ & $1664+1$ & $459+0$ & $1767+17$ & $911+9$ & $131+5$ \\
d & 16.80 & 68.60 & 45.19 & 104.50 & 156.94 & 44.60 \\
e & 8.67 & 33.80 & 10.44 & 134.02 & 41.02 & 10.04 \\
$\mathbf{f}$ & 0.63 & 0.70 & 0.60 & 0.76 & 0.73 & 0.58 \\
$\mathbf{g}$ & 0.87 & -3.21 & 0.20 & 2.34 & 11.03 & -0.84 \\
$\mathbf{h}$ & 8.16 & 1.72 & 2.27 & 0.43 & 4.17 & 1.86 \\
$\mathbf{i}$ & -0.15 & -0.22 & -0.04 & -0.62 & 0.00 & -0.57 \\
$\mathbf{j}$ & 125.51 & 1841.72 & 878.04 & 1129.60 & 303.53 & 1177.27 \\
$\mathbf{k}$ & -1.70 & 3.24 & 6.23 & 2.04 & 5.61 & 3.92 \\
$\mathbf{I}$ & 5.71 & 9.31 & 4.28 & 2.21 & 1.66 & 4.11 \\
$\mathbf{m}$ & Forint & Indian Rupee & $\begin{array}{l}\text { Indonesian } \\
\text { rupiah }\end{array}$ & Won & $\begin{array}{l}\text { Malaysian } \\
\text { ringgit }\end{array}$ & Mexican Peso \\
& & & managed & \\
$\mathbf{n}$ & managed & free float & free float & free float & float after & free float \\
\hline
\end{tabular}


Table 1 continued

\begin{tabular}{|c|c|c|c|c|c|c|}
\hline & Morocco & Peru & Philippines & Poland & Russia & South Africa \\
\hline $\mathbf{a}$ & $\begin{array}{l}\text { Casablanca } \\
\text { SE }\end{array}$ & Lima SE & $\begin{array}{l}\text { Philippine } \\
\text { SE }\end{array}$ & Warsaw SE & $\begin{array}{l}\text { Moscow } \\
\text { Exchange }\end{array}$ & $\begin{array}{l}\text { Johannesburg } \\
\text { SE }\end{array}$ \\
\hline b & CFG 25 & IGBVL & PCOMP & WIG & IndexCF & JALSH \\
\hline c & $76+1$ & $214+63$ & $252+2$ & $844+23$ & $292+1$ & $338+49$ \\
\hline d & 54.41 & 49.13 & 105.55 & 36.29 & 43.41 & 159.33 \\
\hline e & 3.62 & 2.53 & 13.86 & 13.73 & 36.34 & 81.13 \\
\hline f & 0.51 & 0.64 & 0.50 & 0.75 & n.a. & 0.35 \\
\hline g & -8.06 & -1.89 & 3.10 & -4.85 & 5.12 & -3.41 \\
\hline h & 2.54 & 4.65 & 0.81 & 2.97 & 2.90 & 1.47 \\
\hline i & 0.17 & 0.08 & 0.47 & 0.59 & -0.52 & -0.94 \\
\hline $\mathbf{j}$ & 96.73 & 197.11 & 250.27 & 489.80 & 2014.77 & 384.31 \\
\hline $\mathbf{k}$ & 2.71 & 6.28 & 6.59 & 1.90 & 3.44 & 2.55 \\
\hline 1 & 1.28 & 3.65 & 3.17 & 3.75 & 5.07 & 5.41 \\
\hline m & $\begin{array}{l}\text { Moroccan } \\
\text { dirham }\end{array}$ & $\begin{array}{l}\text { Peruvian } \\
\text { nuevo sol }\end{array}$ & $\begin{array}{l}\text { Philippine } \\
\text { peso }\end{array}$ & Zloty & Ruble & Rand \\
\hline $\mathbf{n}$ & $\begin{array}{l}\text { pegged to a } \\
\text { basket }\end{array}$ & free float & free float & free float & $\begin{array}{l}\text { pegged after } \\
2005\end{array}$ & free float \\
\hline
\end{tabular}

\begin{tabular}{|c|c|c|c|c|}
\hline & Taiwan & Thailand & Turkey & Definition \\
\hline $\mathbf{a}$ & $\begin{array}{l}\text { Taiwan SE } \\
\text { Corp. }\end{array}$ & $\begin{array}{l}\text { The SE of } \\
\text { Thailand }\end{array}$ & Borsa Istanbul & Stock Exchange \\
\hline b & TWSE & SET & XU100 & Index \\
\hline c & $783+57$ & $558+0$ & $226+1$ & $\begin{array}{l}\text { Number of Listed Companies in } 2012 \\
\text { (Domestic+Foreign) }\end{array}$ \\
\hline d & 155.13 & 104.77 & 39.12 & $\begin{array}{l}\text { Market capitalization of listed companies (\% } \\
\text { of GDP), } 2012\end{array}$ \\
\hline $\mathbf{e}$ & 145.36 & 62.77 & 44.16 & Stocks traded, total value (\% of GDP) 2012 \\
\hline f & 0.58 & 0.68 & 0.56 & $\begin{array}{l}\text { Share in total market cap of the } 5 \% \text { most } \\
\text { capitalized domestic companies, } 2010\end{array}$ \\
\hline $\mathbf{g}$ & 8.40 & 1.71 & -9.69 & Current account balance (\% of GDP), 2011 \\
\hline $\mathbf{h}$ & -0.29 & 2.25 & 2.07 & $\begin{array}{l}\text { Foreign direct investment, net inflows ( } \% \text { of } \\
\text { GDP) } 2011\end{array}$ \\
\hline $\mathbf{i}$ & n.a. & 0.25 & -0.13 & $\begin{array}{l}\text { Portfolio equity, net inflows (BoP, \%GDP) } \\
2011\end{array}$ \\
\hline $\mathbf{j}$ & 473.97 & 365.56 & 789.26 & GDP (current USD) billions 2012 \\
\hline $\mathbf{k}$ & 1.30 & 6.43 & 2.24 & GDP growth (annual \%) 2012 \\
\hline 1 & 1.61 & 3.01 & 8.89 & Inflation, consumer prices (annual \%) 2012 \\
\hline $\mathbf{m}$ & $\begin{array}{l}\text { New Taiwan } \\
\text { Dollar }\end{array}$ & Baht & Turkish Lira & Currency \\
\hline $\mathbf{n}$ & managed float & managed float & managed float & Exchange Rate Regime \\
\hline
\end{tabular}


The countries are quite different in many aspects so it is not easy to form an ad hoc expectation as to the nature of the interaction between stock prices and exchange rates. The number of companies listed in the stock exchange varies on a large spectrum with only 29 companies listed on the Prague Stock Exchange and 1767 companies on the Korea Exchange. Listing of foreign companies is not a prevalent feature. There are only seven countries where listing of foreign companies is considerable, namely Brazil, Chile, South Korea, Peru, Poland, South Africa, and Taiwan. The size of the stock market relative to GDP varies remarkably with Hungary at the low end of the spectrum while in Malaysia, South Africa and Taiwan market capitalization of listed companies are as large as 1.5 times their respective 2012 GDPs. In terms of trade volume South Korea and Taiwan seem to have the lead. Market concentration seems to be similar across these countries with the total market capitalization of the top 5\% of most capitalized domestic companies in 2010 constituting about half of the total market capitalizaiton, with the exception of India, South Korea, Malaysia and Poland. Current account balance as a percentage of 2011 GDP is quite low for most countries with Morocco and Turkey carrying the largest deficits and Malaysia and Taiwan carrying the largest surpluses. Net FDI inflows in 2011 are almost negligable for most of these countries except for Chile and Hungary. Net portfolio inflows in 2011 are less than 1\% of the countries' respective GDPs with the exception of Chile. Brazil, South Korea, Mexico and Russia are the largest economies in the sample. The annual GDP growth reported in 2012 is above $6 \%$ for China, Indonesia, Peru, Philippines and Thailand while the Czech Republic and Hungary reported negative growth in 2012. The inflation rate reported in 2012 is in the low single digits, with the exception of India and Turkey Lastly exchange rate regimes are not uniform across these 21 countries. While most of these economies can be characterized by a managed float, Morocco and Russia have explicit peg arrangements.

\section{Methodology and Empirical Results}

The ability of one variable to predict another variable is discussed in terms of the concept of Granger causality. This defintion is specifically related to the issue of predictability and is different from theoretical, logical or experimental definitions of the concept. Formally, consider the stationary bivariate $\operatorname{VAR}(\mathrm{p})$ :

$$
\begin{aligned}
& x_{t}=\alpha_{0}+\sum_{j=1}^{p} a_{j} x_{t-j}+\sum_{j=1}^{p} b_{j} y_{t-j}+u_{x t} \\
& y_{t}=c_{0}+\sum_{j=1}^{p} c_{j} x_{t-j}+\sum_{j=1}^{p} d_{j} y_{t-j}+u_{y t}
\end{aligned}
$$

In this framework $x$ does not Garanger cause $y$ if $c_{j}=0, \forall j=1, \ldots, p$ and $y$ does not Garanger cause $x$ if $b_{j}=0, \forall j=1, \ldots, p$. Testing for non-causality, then, boils down to a joint significance test on the parameters of the lagged independent variables in each of the VAR equations. Table 2 presents the results of the conventional Granger non-causality tests on our data.

\begin{tabular}{|c|c|c|c|c|c|c|c|}
\hline Countries & $\mathrm{p}$ & Null Hypothesis & F statistic & Countries & $\mathrm{p}$ & Null Hypothesis & F statistic \\
\hline \multirow[t]{2}{*}{ Brazil } & 1 & $\mathrm{EX} \not>\mathrm{SP}$ & 1.08 & Mexico & 1 & $\mathrm{EX} \not>\mathrm{SP}$ & $5.30 * *$ \\
\hline & & $\mathrm{SP} \not>\mathrm{EX}$ & $5.02 * *$ & & & $\mathrm{SP} \neq>\mathrm{EX}$ & 1.32 \\
\hline \multirow[t]{2}{*}{ Chile } & 1 & $\mathrm{EX} \not>\mathrm{SP}$ & 1.98 & Morocco & 1 & $\mathrm{EX} \not>\mathrm{SP}$ & 0.00 \\
\hline & & $\mathrm{SP} \neq>\mathrm{EX}$ & $6.02 * *$ & & & $\mathrm{SP} \neq>\mathrm{EX}$ & $6.11^{* *}$ \\
\hline \multirow[t]{2}{*}{ China } & 1 & $\mathrm{EX} \not>\mathrm{SP}$ & 0.49 & Peru & 1 & $\mathrm{EX} \neq>\mathrm{SP}$ & 2.52 \\
\hline & & $\mathrm{SP} \not>\mathrm{EX}$ & $20.38 * * *$ & & & $\mathrm{SP} \neq>\mathrm{EX}$ & $6.16^{* *}$ \\
\hline \multirow[t]{2}{*}{ Colombia } & 1 & $\mathrm{EX} \neq>\mathrm{SP}$ & 0.15 & Philippines & 1 & $\mathrm{EX} \neq>\mathrm{SP}$ & 1.59 \\
\hline & & $\mathrm{SP} \not>\mathrm{EX}$ & $3.74 *$ & & & $\mathrm{SP} \neq>\mathrm{EX}$ & $6.65^{* *}$ \\
\hline \multirow[t]{2}{*}{ Czech Rep } & 1 & $\mathrm{EX} \not>\mathrm{SP}$ & $7.12 * * *$ & Poland & 1 & $\mathrm{EX} \not>\mathrm{SP}$ & $11.10^{* * *}$ \\
\hline & & $\mathrm{SP} \neq>\mathrm{EX}$ & 2.51 & & & $\mathrm{SP} \neq>\mathrm{EX}$ & $5.76^{* *}$ \\
\hline \multirow[t]{2}{*}{ Egypt } & 2 & $\mathrm{EX} \neq>\mathrm{SP}$ & $6.25^{* *}$ & Russia & 1 & $\mathrm{EX} \not>\mathrm{SP}$ & $10.07 * * *$ \\
\hline & & $\mathrm{SP} \neq>\mathrm{EX}$ & 3.41 & & & $\mathrm{SP} \neq>\mathrm{EX}$ & 0.64 \\
\hline
\end{tabular}

Table 2. Granger Non-Causality Tests 


\begin{tabular}{|c|c|c|c|c|c|c|c|}
\hline \multirow[t]{2}{*}{ Hungary } & 1 & $\mathrm{EX} \neq>\mathrm{SP}$ & $3.67 *$ & South Africa & 1 & $\mathrm{EX} \neq>\mathrm{SP}$ & 1.03 \\
\hline & & $\mathrm{SP} \not>\mathrm{EX}$ & 0.50 & & & $\mathrm{SP} \neq>\mathrm{EX}$ & $7.67 * *$ \\
\hline \multirow[t]{2}{*}{ India } & 1 & $\mathrm{EX} \neq>\mathrm{SP}$ & 1.50 & Taiwan & 1 & $\mathrm{EX} \neq>\mathrm{SP}$ & 1.65 \\
\hline & & $\mathrm{SP} \not>\mathrm{EX}$ & $2.93^{*}$ & & & $\mathrm{SP} \neq>\mathrm{EX}$ & $3.74^{*}$ \\
\hline \multirow[t]{2}{*}{ Indonesia } & 2 & $\mathrm{EX} \neq>\mathrm{SP}$ & 4.02 & Thailand & 1 & $\mathrm{EX} \neq>\mathrm{SP}$ & 0.04 \\
\hline & & $\mathrm{SP} \neq>\mathrm{EX}$ & $10.03 * * *$ & & & $\mathrm{SP} \neq>\mathrm{EX}$ & 0.00 \\
\hline \multirow[t]{2}{*}{ Korea } & 1 & $\mathrm{EX} \neq>\mathrm{SP}$ & 0.38 & Turkey & 2 & $\mathrm{EX} \not>\mathrm{SP}$ & $9.52 * * *$ \\
\hline & & $\mathrm{SP} \neq>\mathrm{EX}$ & 0.07 & & & $\mathrm{SP} \neq>\mathrm{EX}$ & 4.05 \\
\hline \multirow[t]{2}{*}{ Malysia } & 1 & $\mathrm{EX} \not>\mathrm{SP}$ & 1.15 & & & & \\
\hline & & $\mathrm{SP} \not>\mathrm{EX}$ & $13.17 * * *$ & & & & \\
\hline
\end{tabular}

Note:*, ${ }^{* *}$ and ${ }^{* * *}$ indicate the rejection of the null hypothesis for $\alpha=0.10 \alpha=0.05$ and $\alpha=0.01$ respectively

Granger non-causality test has a limitation in that it can only be used when the variables entering the VAR are stationary. Like most financial variables stock indices and exchange rates, however, are not usually stationary. Phillips-Perron and Kwiatkowski-Phillips-Schmidt-Shin unit root tests presented in Table 3 reveal that our data set is no exception.

Table 3. Unit root tests

\begin{tabular}{|c|c|c|c|c|c|}
\hline \multirow[t]{2}{*}{ Countries } & & \multicolumn{2}{|c|}{ PP } & \multicolumn{2}{|c|}{ KPPS } \\
\hline & & level & difference & level & difference \\
\hline \multirow[t]{2}{*}{ Brazil } & SP & $-2.93 *$ & $-8.89 * * *$ & $1.10 * * *$ & $0.47 * *$ \\
\hline & EX & -2.46 & $-10.50 * * *$ & $0.97 * * *$ & 0.33 \\
\hline \multirow[t]{2}{*}{ Chile } & $\mathrm{SP}$ & -2.47 & $-9.44 * * *$ & $1.26 * * *$ & 0.31 \\
\hline & EX & $-2.73 *$ & $-10.15^{* * *}$ & $0.91 * * *$ & 0.12 \\
\hline \multirow[t]{2}{*}{ China } & $\mathrm{SP}$ & -1.76 & -10.66 & $0.55^{* *}$ & 0.10 \\
\hline & EX & 0.27 & $-9.72 * * *$ & $1.32 * * *$ & 0.16 \\
\hline \multirow[t]{2}{*}{ Colombia } & $\mathrm{SP}$ & $-2.93 * *$ & $-9.15 * * *$ & $1.06 * * *$ & $0.59 * *$ \\
\hline & EX & -1.98 & $-10.59 * * *$ & $1.16^{* * *}$ & 0.08 \\
\hline \multirow[t]{2}{*}{ Czech Rep. } & SP & -2.57 & $-8.79 * * *$ & 0.27 & $0.40^{*}$ \\
\hline & EX & -2.16 & $-10.97 * * *$ & $1.00 * * *$ & 0.16 \\
\hline \multirow[t]{2}{*}{ Egypt } & $\mathrm{SP}$ & $-3.11 * *$ & $-8.80 * * *$ & $0.64 * *$ & $0.53^{*}$ \\
\hline & EX & -0.53 & $-6.95 * * *$ & 0.31 & 0.25 \\
\hline \multirow[t]{2}{*}{ Hungary } & SP & -2.53 & $-9.14 * * *$ & $0.47 * *$ & 0.25 \\
\hline & EX & $-2.74 *$ & $-11.18 * * *$ & 0.23 & 0.07 \\
\hline \multirow[t]{2}{*}{ India } & $\mathrm{SP}$ & -2.17 & -10.36 & $1.15^{* * *}$ & 0.20 \\
\hline & EX & -0.49 & $-9.13 * * *$ & $0.57 * *$ & 0.29 \\
\hline \multirow[t]{2}{*}{ Indonesia } & $\mathrm{SP}$ & -1.87 & $-8.82 * * *$ & $1.27 * * *$ & 0.15 \\
\hline & EX & -2.56 & $-9.44 * * *$ & 0.18 & 0.04 \\
\hline \multirow[t]{2}{*}{ Korea } & $\mathrm{SP}$ & -2.21 & $-11.06^{* * *}$ & $1.11 * * *$ & 0.19 \\
\hline & EX & -2.05 & $-12.07 * * *$ & 0.20 & 0.10 \\
\hline \multirow[t]{2}{*}{ Malaysia } & $\mathrm{SP}$ & -1.28 & $-9.97 * * *$ & $1.17 * * *$ & 0.05 \\
\hline & EX & -1.14 & $-11.95^{* * *}$ & $1.19 * * *$ & 0.06 \\
\hline \multirow[t]{2}{*}{ Mexico } & $\mathrm{SP}$ & -2.53 & $-10.02 * * *$ & $1.19 * * *$ & $0.35^{*}$ \\
\hline & EX & -1.80 & $-9.70 * * *$ & $0.89 * * *$ & 0.03 \\
\hline
\end{tabular}




\begin{tabular}{|c|c|c|c|c|c|}
\hline \multirow[t]{2}{*}{ Morocco } & SP & -2.47 & $-10.81 * * *$ & $0.91 * * *$ & $0.66^{* *}$ \\
\hline & EX & $-2.92 * *$ & $-11.45^{* * *}$ & $0.60 * *$ & 0.12 \\
\hline \multirow[t]{2}{*}{ Peru } & SP & -2.19 & $-9.97 * * *$ & $1.09 * * *$ & 0.30 \\
\hline & EX & -1.26 & $-10.82 * * *$ & $1.29 * * *$ & 0.06 \\
\hline \multirow[t]{2}{*}{ Philippines } & $\mathrm{SP}$ & -1.04 & $-10.85^{* * *}$ & $1.17 * * *$ & 0.08 \\
\hline & EX & -1.05 & $-10.03 * * *$ & $1.13 * * *$ & 0.08 \\
\hline \multirow[t]{2}{*}{ Poland } & $\mathrm{SP}$ & $-2.61^{*}$ & $-10.31 * * *$ & $0.65^{* *}$ & 0.24 \\
\hline & EX & -2.31 & $-10.01 * * *$ & $0.43 *$ & 0.10 \\
\hline \multirow[t]{2}{*}{ Russia } & SP & -2.56 & $-8.46 * * *$ & $0.82 * * *$ & 0.23 \\
\hline & EX & -2.09 & $-9.41 * * *$ & 0.32 & 0.14 \\
\hline \multirow[t]{2}{*}{ South Africa } & $\mathrm{SP}$ & -1.49 & $-11.57 * * *$ & $1.15^{* * *}$ & 0.17 \\
\hline & EX & -1.88 & $-11.89 * * *$ & $0.60 * *$ & 0.21 \\
\hline \multirow[t]{2}{*}{ Taiwan } & SP & -2.42 & $-9.68 * * *$ & $0.64 * *$ & 0.04 \\
\hline & EX & -1.89 & $-9.53 * * *$ & $1.01 * * *$ & 0.03 \\
\hline \multirow[t]{2}{*}{ Thailand } & SP & -1.68 & $-9.30 * * *$ & $0.87 * * *$ & 0.08 \\
\hline & EX & -1.41 & $-9.49 * * *$ & $1.28 * * *$ & 0.08 \\
\hline \multirow[t]{2}{*}{ Turkey } & $\mathrm{SP}$ & -1.94 & $-11.75^{* * *}$ & $1.10 * * *$ & 0.14 \\
\hline & EX & -1.41 & $-10.21 * * *$ & $0.73^{* *}$ & 0.19 \\
\hline
\end{tabular}

Note:*, ** and *** indicate the rejection of the null hypothesis for $\alpha=0.10 \alpha=0.05$ and $\alpha=0.01$ respectively

Toda and Yamomoto (1995) adress this limitation of the test and develop an extension which is valid for non-stationary variables. Toda-Yamomoto test involves augmenting the order of the VAR by the maximum order of integration of the variables so that if a $\operatorname{VAR}(p)$ is to be estimated for some $\mathrm{I}(\mathrm{d})$ variables the VAR is augmented to $(p+d)$ lags. Then the joint significance of the parameters on only the first $p$ lags of the independent variables in each of the VAR equations is tested. Table 4 reports the results for the Toda-Yamomoto tests on our data.

Table 4. Toda-Yamamoto tests

\begin{tabular}{llllllll} 
Countries & $\mathrm{p}+\mathrm{d}$ & Null Hypothesis & WALD & Countries & $\mathrm{p}+\mathrm{d}$ & Null Hypothesis & WALD \\
\hline Brazil & 2 & EX $\neq>$ SP & 0.31 & Mexico & 2 & EX $\neq>$ SP & 0.44 \\
& & SP $\neq>$ EX & $4.47^{* *}$ & & & SP $\neq>$ EX & 0.19 \\
Chile & 2 & EX $\neq>$ SP & 0.00 & Morocco & 2 & EX $\neq>$ SP & 0.09 \\
& & SP $\neq>$ EX & 0.03 & & & SP $\neq>$ EX & 0.71 \\
China & 2 & EX $\neq>$ SP & 1.04 & Peru & 2 & EX $\neq>$ SP & 2.31 \\
& & SP $\neq>$ EX & 0.04 & & & SP $\neq>$ EX & $3.10^{*}$ \\
Colombia & 2 & EX $\neq>$ SP & $6.84^{* * *}$ & Philippines & 2 & EX $\neq>$ SP & 0.10 \\
& & SP $\neq>$ EX & 0.71 & & & SP $\neq>$ EX & 1.42 \\
Czech Rep. & 2 & EX $\neq>$ SP & 2.02 & Poland & 2 & EX $\neq>$ SP & 1.47 \\
& & SP $\neq>$ EX & $3.15^{*}$ & & & SP $\neq>$ EX & 0.00 \\
Egypt & 2 & EX $\neq>$ SP & $5.27^{*}$ & Russia & 2 & EX $\neq>$ SP & 0.59 \\
& & SP $\neq>$ EX & $6.06^{* *}$ & & & SP $\neq>$ EX & $2.74 *$ \\
Hungary & 2 & EX $\neq>$ SP & 0.01 & South Africa & 2 & EX $\neq>$ SP & $3.18^{*}$ \\
& & SP $\neq>$ EX & $3.56^{*}$ & & & SP $\neq>$ EX & $5.20^{* *}$ \\
India & 2 & EX $\neq>$ SP & 1.04 & Taiwan & 2 & EX $\neq>$ SP & 0.10 \\
& & SP $\neq>$ EX & 0.19 & & & SP $\neq>$ EX & 2.58 \\
Indonesia & 2 & EX $\neq>$ SP & 1.58 & Thailand & 2 & EX $\neq>$ SP & 0.04
\end{tabular}




\begin{tabular}{|c|c|c|c|c|c|c|c|}
\hline & & $\mathrm{SP} \neq>\mathrm{EX}$ & $8.53 * *$ & & & $\mathrm{SP} \neq>\mathrm{EX}$ & $3.12 *$ \\
\hline \multirow[t]{2}{*}{ Korea } & 2 & $\mathrm{EX} \not>\mathrm{SP}$ & 0.75 & Turkey & 2 & $\mathrm{EX} \not>\mathrm{SP}$ & 0.00 \\
\hline & & $\mathrm{SP} \neq>\mathrm{EX}$ & $4.84 * *$ & & & $\mathrm{SP} \neq>\mathrm{EX}$ & 0.19 \\
\hline \multirow[t]{2}{*}{ Malaysia } & 2 & $\mathrm{EX} \not>\mathrm{SP}$ & 0.05 & & & & \\
\hline & & $\mathrm{SP} \neq>\mathrm{EX}$ & $4.72 * *$ & & & & \\
\hline
\end{tabular}

Note:*, ** and *** indicate the rejection of the null hypothesis for $\alpha=0.10 \alpha=0.05$ and $\alpha=0.01$ respectively

This test, too, has some limitations in that the distribution of the test statistic diverges from the presupposed chi square distribution when there are ARCH effects and when the residual distribution for the $\operatorname{VAR}(p+d)$ is not normal, which is usually the case in small samples. Table 5 presents multivariate ARCH-LM and normality tests (Doornik-Hansen) for our data, which turns out to be suffering from both problems.

Table 5. Multivariate ARCH and Normality Tests

\begin{tabular}{llllllll} 
Countries & $\mathrm{p}+\mathrm{d}$ & ARCH-LM & Normality & Countries & $\mathrm{p}+\mathrm{d}$ & ARCH-LM & Normality \\
\hline Brazil & 2 & 56.22 & $17.54^{* * *}$ & Mexico & 2 & $79.31^{* * *}$ & $27.35^{* * *}$ \\
Chile & 2 & 26.04 & $38.12^{* * *}$ & Morocco & 2 & 50.89 & $42.05^{* * *}$ \\
China & 2 & 53.95 & $44.80^{* * *}$ & Peru & 2 & $141.99^{* * *}$ & $68.07^{* * *}$ \\
Colombia & 2 & $68.54^{* * *}$ & $14.04^{* * *}$ & Philippines & 2 & $78.95^{* * *}$ & $19.01^{* * *}$ \\
Czech & 2 & $101.58^{* * *}$ & $15.75^{* * *}$ & Poland & 2 & 48.58 & $11.69^{* * *}$ \\
Egypt & 3 & $67.88^{* * *}$ & $69.60^{* * *}$ & Russia & 2 & $96.72^{* * *}$ & $99.50^{* * *}$ \\
Hungary & 2 & $84.13^{* * *}$ & $19.91^{* * *}$ & South Africa & 2 & $78.11^{* * *}$ & $15.75^{* * *}$ \\
India & 2 & $60.49^{*}$ & $18.01^{* * *}$ & Taiwan & 2 & $74.24 * * *$ & $16.78^{* * *}$ \\
Indonesia & 2 & $150.58^{* * *}$ & $30.96^{* * *}$ & Thailand & 2 & $64.82^{* *}$ & $34.69^{* * *}$ \\
Korea & 2 & $146.08^{* * *}$ & $39.32^{* * *}$ & Turkey & 3 & 50.92 & $25.57^{* * *}$ \\
Malaysia & 2 & $68.49^{* * *}$ & $29.00^{* * *}$ & & & & \\
\hline
\end{tabular}

Note:*,** and $* * *$ indicate the rejection of the null hypothesis for $\alpha=0.10 \alpha=0.05$ and $\alpha=0.01$ respectively

Hacker and Hatemi-J (2006) develop a bootstrapping procedure to establish the sample distribution of the test statistic and later in Hacker and Hatemi-J $(2010,2012)$ extend the procedure to endogenize the lag length choice for the $\operatorname{VAR}(p)$. Their simulation results suggest this procedure leads to an improvement in size and power properties of the test in comparison to the Toda and Yamamoto methodology.

Since our data is nonstationary and fails the multivariate $\mathrm{ARCH}$ and normality tests, under the circumstances, Hacker and Hatemi-J (2010) procedure is preferable to both Granger and Toda-Yamomoto tests. Table 6 presents the results of the Hacker and Hatemi-J (2010) test for the 21 countries in our data set.

Table 6. Hacker-Hatemi-J Non-Causality Test

\begin{tabular}{llllllll} 
Country & $\mathrm{p}$ & Null Hypothesis & MWALD statistic & Country & $\mathrm{p}$ & Null Hypothesis & MWALD statistic \\
\hline Brazil & 1 & EX $\neq>$ SP & 0.31 & Mexico & 1 & EX $\neq>$ SP & 0.45 \\
& & SP $\neq>$ EX & $4.48^{*}$ & & & SP $\neq>$ EX & 0.19 \\
Chile & 1 & EX $\neq>$ SP & 0 & Morocco & 1 & EX $\neq>$ SP & 0.09
\end{tabular}




\begin{tabular}{|c|c|c|c|c|c|c|c|}
\hline & & $\mathrm{SP} \neq>\mathrm{EX}$ & 0.03 & & & $\mathrm{SP} \neq>\mathrm{EX}$ & 0.71 \\
\hline \multirow[t]{2}{*}{ China } & 1 & $\mathrm{EX} \not>\mathrm{SP}$ & 1.04 & Peru & 1 & $\mathrm{EX} \neq>\mathrm{SP}$ & 2.32 \\
\hline & & $\mathrm{SP} \neq>\mathrm{EX}$ & 0.04 & & & $\mathrm{SP} \neq>\mathrm{EX}$ & $3.11 *$ \\
\hline \multirow[t]{2}{*}{ Colombia } & 1 & $\mathrm{EX} \neq>\mathrm{SP}$ & $6.84 *$ & Philippines & 1 & $\mathrm{EX} \neq>\mathrm{SP}$ & 0.11 \\
\hline & & $\mathrm{SP} \not>\mathrm{EX}$ & 0.71 & & & $\mathrm{SP} \neq>\mathrm{EX}$ & 1.43 \\
\hline \multirow[t]{2}{*}{ Czech } & 1 & $\mathrm{EX} \not>\mathrm{SP}$ & 2.02 & Poland & 1 & $\mathrm{EX} \not>\mathrm{SP}$ & 1.48 \\
\hline & & $\mathrm{SP} \neq>\mathrm{EX}$ & $3.16^{*}$ & & & $\mathrm{SP} \neq>\mathrm{EX}$ & 0.01 \\
\hline \multirow[t]{2}{*}{ Egypt } & 1 & $\mathrm{EX} \not>\mathrm{SP}$ & $5.27^{*}$ & Russia & 1 & $\mathrm{EX} \not>\mathrm{SP}$ & 0.59 \\
\hline & & $\mathrm{SP} \not>\mathrm{EX}$ & $6.07 *$ & & & $\mathrm{SP} \not>\mathrm{EX}$ & 2.75 \\
\hline \multirow[t]{2}{*}{ Hungary } & 1 & $\mathrm{EX} \neq>\mathrm{SP}$ & 0.02 & South Africa & 1 & $\mathrm{EX} \neq>\mathrm{SP}$ & $3.19^{*}$ \\
\hline & & $\mathrm{SP} \neq>\mathrm{EX}$ & $3.57^{*}$ & & & $\mathrm{SP} \neq>\mathrm{EX}$ & $5.21 *$ \\
\hline \multirow[t]{2}{*}{ India } & 1 & $\mathrm{EX} \not>\mathrm{SP}$ & 1.04 & Taiwan & 1 & $\mathrm{EX} \neq>\mathrm{SP}$ & 0.11 \\
\hline & & $\mathrm{SP} \neq>\mathrm{EX}$ & 0.19 & & & $\mathrm{SP} \neq>\mathrm{EX}$ & 2.59 \\
\hline \multirow[t]{2}{*}{ Indonesia } & 1 & $\mathrm{EX} \not>\mathrm{SP}$ & 0.73 & Thailand & 1 & $\mathrm{EX} \neq>\mathrm{SP}$ & 0.05 \\
\hline & & $\mathrm{SP} \not>\mathrm{EX}$ & $7.74 *$ & & & $\mathrm{SP} \neq>\mathrm{EX}$ & $3.12 *$ \\
\hline \multirow[t]{2}{*}{ Korea } & 1 & $\mathrm{EX} \not>\mathrm{SP}$ & 0.76 & Turkey & 1 & $\mathrm{EX} \not>\mathrm{SP}$ & 2.27 \\
\hline & & $\mathrm{SP} \neq>\mathrm{EX}$ & $4.84^{*}$ & & & $\mathrm{SP} \neq>\mathrm{EX}$ & 0.00 \\
\hline \multirow[t]{2}{*}{ Malaysia } & 1 & $\mathrm{EX} \not>\mathrm{SP}$ & 0.06 & & & & \\
\hline & & $\mathrm{SP} \neq>\mathrm{EX}$ & $5.72 *$ & & & & \\
\hline
\end{tabular}

Note:*, ${ }^{*}$ and $* * *$ indicate the rejection of the null hypothesis for $\alpha=0.10 \alpha=0.05$ and $\alpha=0.01$ respectively

The results are mixed as expected. Over our sample period, in Brazil, Czech Republic, Hungary, Indonesia, Korea, Malaysia, Peru and Thailand, there is evidence of stock prices leading the exchange rate. In Colombia evidence points to the exchange rate leading stock prices. In Egypt and South Africa there seems to be a feedback between stock prices and the exchange rate, whereas in all other countries the two variables do not seem to contribute to each other's predictions.

Such mixed results are common in the literature, as discussed above. Table 1 reveals the diversity among these countries in terms of the dept and concentration of the stock market, intensity of international portfolio flows and macroeconomic balances. Keeping in mind that results are sensitive to the choice of sample period and the frequency of data we can conclude that during the last decade, in the context of the 2008 global crisis, in 11 of the emerging market economies included in the MSCI index, there is statistically significant interaction between stock prices and the exchange rate. In eight of these 11 economies, evidence supports the portfolio balance approach with stock prices leading the exchange rate. In only one of the economies there is evidence in favor of the traditional approach.

\section{Conclusion}

Investigating the direction of causality between stock prices and exchange rates has received the attention of a growing number of researchers since 1980s. Most of the empirical research in this regard has focused on advanced economies. Yet emerging market economies are more prone to volatility in stock markets and currency markets because of their structural weaknesses. Understanding the linkages between the stock market and the foreign exchange market is more important for policy design in these economies.

The 2008 global crisis once more revealed that emerging market economies are well integrated into the global financial system through their liberalized capital accounts and financial markets. Short term international capital movements have a greater role in determining their fate than any domestic factor. Thus the percieved safety and growth potential of a country by the international finance community is almost self-fulfilling. 
In developing countries, the financial system is characterized by opaqueness, whereby the degree and the source of risks are unknown. This opaqueness increases whenever there is a weak regulatory framework and a lack of market discipline (Antzoulatos, 2012). Financial economists expect that because of the financial fragility of emerging market economies, negative expectations initially affect the stock market initiating adverse capital account dynamics and consequent depreciation of currencies. When we consider the 2008 global financial crisis, stock market indices seem to be driving exchange rates.

This study provides an opportunity to evaluate this observation for the 21 countries in the MSCI-EM index. Our empirical findings, based on the Hacker and Hatemi-J (2010) bootstrap non-causality test, indicate that there is no universal pattern for the causal relationship between stock prices and exchange rates in emerging market economies. The results for Brazil, Czech Republic, Hungary, Indonesia, Korea, Malaysia, Peru and Thailand provide evidence in support of "stock oriented models" or "portfolio balance approach", in that stock prices lead exchange rates. In these countries, policy makers should focus on the stock markets to reduce the exchange rate fluctuations during the financial crises. On the other hand, the data for Colombia support the "traditional approach" or flow oriented models", which hypothesizes that exchange rate leads stock prices. In this case, stabilizing exchange rates should be the priority of policy to prevent high volatility in stock prices. In Egypt and South Africa there seems to be a feedback between these variables, while no statistically significant relationship was found for the remaining countries.

Once diagnosed, emerging market economies can exploit such a link in policy design. Moreover, economic agents can also use this information for forecasting the behavior of stock prices and exchange rates. Contrary to many studies which have found no relationship between these variables, our findings indicate that the relationship exists in most emerging market economies and can potentially be used to stabilize financial markets.

\section{References}

Abdalla, I.S.A., \& V. Murinde. (1997). Exchange Rate and Stock Price Interactions in Emerging Financial Markets: Evidence on India, Korea, Korea, Pakistan and The Philippines. Applied Financial Economics, 7, 25-35. http://dx.doi.org/10.1080/096031097333826.

Agrawal, G., Srivastav, A.K., \& A. Srivastava. (2010). Study of Exchange Rates Movement and Stock Market Volatility. International Journal of Business and Management, 5(12), 62-73.

Antzoulatos, A. A. (2012). Policy Responses to the European Debt Crisis Treating the Syptoms or the Disease ? Panoeconomicus, 5, 529-552. http://dx.doi.org/10.2298/PAN1205529A

Ayaji A.R., Joseph F.R., \& S. M. Mehdian. (1998). On the Relationship Between Stock Returns and Exchange Rates: Test of Granger Causality. Global Finance Journal, 9(2), 241-251. http://dx.doi.org/doi:10.1016/S1044-0283(98)90006-0.

Bahmani-Oskooee, M., \& A. Sohrabian. (1992). Stock Prices and the Effective Exchange Rate of Dollar. Applied Economics, 24(4), 459-464. http://dx.doi.org/10.1080/00036849200000020

Beer, F., \& F. Habein. (2008). An Assessment of the Stock Market and Exchange Rate Dynamics in Industrialized and Emerging Markets. International Business and Economics Research Journal, 7(8), 59-70. http://dx.doi.org/10.19030/iber.v7i8.3283

Dimitrova, D. (2005). The Relationships between Exchange Rate and Stock Prices, Issues in Political Economy, 14.

Doornik, J. A., \& H. Hansen. (2008). An Omnibus Test for Univariate and Multivariate Normality. Oxford Bulletin of Economics and Statistics, 70, 927-939. http://dx.doi.org/10.1111/j.1468-0084.2008.00537.x

Dornbusch, R. (2001). A Primer on Emerging Market Crises, NBER Working Paper 8326. http://dx.doi.org/10.3386/w8326

Duric M., D. (2006). Some of the Unanswered Questions in Finance, Panoeconomicus, 2, 223-230. http://dx.doi.org/10.2298/PAN0602223D

Granger, C.W.J., Huan, B., \& C.W.Yang (1998). A Bivariate Causality between Stock Prices and Exchange Rates: Evidence from Recent Asian Flu, UC San Diego Discussion Paper 98-09.

Granger, C.W.J., Huan, B., \& C.W.Yang. (2000). A Bivariate Causality between Stock Prices and Exchange Rates: Evidence from Recent Asian Flu. The Quarterly Review of Economics and Finance, 40, 337-354. http://dx.doi.org/10.1016/S1062-9769(00)00042-9 
Hacker, S.R., \& A. Hatemi-J. (2006). Tests for Causality Between Integrated Variables Using Asymptotic and Bootstrap Distributions: Theory and Application. Applied Economics, 38(13), 1489-1500. http://dx.doi.org/10.1080/00036840500405763

Hacker, S.R., \& A. Hatemi-J. (2010). A Bootstrap Test for Causality with Endogenous Lag Length Choice: Theory and Application in Finance. Working Paper Series in Economics and Institutions of Innovation Royal Institute of Technology, CESIS, 223.

Hacker, S.R., \& A. Hatemi-J. (2012). A Bootstrap Test for Causality with Endogenous Lag Length Choice: Theory and Application in Finance. Journal of Economic Studies, 39(2), 144-160. http://dx.doi.org/10.1108/01443581211222635

Hatemi-J, A., \& E. Roca. (2005). Exchange Rates and Stock Prices Interaction During Good and Bad Times: Evidence From The ASEAN Countries. Applied Financial Economics, 15, 539-546. http://dx.doi.org/10.1080/09603100500056635

Ibrahim, M.H., \& H. Aziz. (2003). Macroeconomics Variables and the Malaysian Equity Market: A View Through Rolling Subsamples. Journal of Economic Studies, 1, 6-27.

Mahmood, W. M., \& N.M. Dinniah. (2007). Stock Returns and Macroeconomic Influences: Evidence from the Six Asian-Pacific Countries. Financial Economics and Futures Market Research Paper, 1-21. http://dx.doi.org/10.1108/01443580310455241

Mazila, M.Y., \& H.A. Rahman. (2013). Granger Causality Relationship Between Malaysia Equity Market and Exchange Rate Volatility, International Journal of Trade, Economics and Finance, 4(1), 19-24. http://dx.doi.org/10.7763/IJTEF.2013.V4.254

Mishkin, F.S. (2001). Financial Policies and the Prevention of Financial Crises in Emerging Market Countries. NBER Working Paper 8087.

Moorley, B. (2002). Exchange Rates and Stock Prices: Implications for European Convergence. Journal of Policy Modeling, 24(5), 523-526.

Muhammed, N., \& A. Rasheed. (2002). Stock Prices and Exchange Rates: Are they Related? Evidence from South Asian Countries. The Pakistan Development Review, 41(4), 535-550.

Muller, A., \& W.F.C. Verschoor. (2006). European Foreign Exchange Risk Exposure. European Financial Management, 12(2), 195-220. http://dx.doi.org/10.1111/j.1354-7798.2006.00316.x

Nieh, C., \& C. Lee. (2001). Dynamic Relationship Between Stock Prices and Exchange Rate for G7 Countries. Quarterly Review of Economics and Finance, 41, 477-490. http://dx.doi.org/10.1016/S1062-9769(01)00085-0

Pan, M.S., Fok, R.C.W., \& Y.A. Liu. (2007). Dynamic Linkages Between Exchange Rates and Stock Prices: Evidence from East Asian Markets. International Review of Economics and Finance, 16, 503-520. http://dx.doi.org/10.1016/j.iref.2005.09.003

Rahman, L.M.D., \& J. Uddin. (2009). Dynamic Relationship Between Stock Prices and Exchange Rates: Evidence from three South Asian Countries. International Business Research, 2(2), 164-174. http://dx.doi.org/10.5539/ibr.v2n2p167

Ray, S. (2012). Testing Granger Causal Relationship between Macroeconomic Variables and Stock Price Behaviour: Evidence from India. Advances in Applied Economics and Finance, 3(1), 470-481.

Richards, N.D., Simpson, J., \& J. Evans. (2009). The Interaction between Exchange Rates and Stock Prices: An Australian Context. International Journal of Economics and Finance, 1(1), 3-23.

Smith, C. E. (1992). Stock Market and The Exchange Rate: A Multi-country Approach. Journal of Macroeconomics.

Smyth, R., \& M. Nandha. (2003). Bivariate Causality between Exchange Rates and Stock Prices in South Asia. Applied Economics Letters, 10(11), 699-704. http://dx.doi.org/10.1080/1350485032000133282

Stavarek, D. (2005). Stock Prices and Exchange Rates in the EU and the USA: Evidence of their Mutual Interactions. Czech Journal of Economics and Finance, 55(3-4), 141-161.

Yang, S. Y., \& S.C. Doong. (2004). Price and Volatility Spillovers between Stock Prices and Exchange Rates: Empirical Evidence from the G-7 Countries. International Journal of Business and Economics, 3(2), $139-153$. 